\title{
Evaluation of microbiological purity of the atmospheric air within the municipal waste landfill in Leśno Górne \\ Ocena czystości mikrobiologicznej powietrza atmosferycznego w obrębie składowiska odpadów komunalnych w Leśnie Górnym
}

\footnotetext{
* Dr Małgorzata Falencka-Jabłońska, mgr inż. Andrzej Skorupa, Department of Forest Ecology, Forest Research Institute, Braci Leśnej 3 St., Sękocin Stary, 05-090 Raszyn, e-mail: falenckm@ibles.waw.pl, a.skorupa1988@op.pl
}

Keywords: bacteria, bioaerosol, fungi, microorganisms, municipal waste, actinomycetes, air pollution, landfill

Słowa kluczowe: bakterie, bioaerozol, grzyby, mikroorganizmy, odpady komunalne, promieniowce, skażenie powietrza, składowisko

\section{Abstract}

Municipal waste landfills are a source of microbial contamination. The aim of the study was to determine the degree of air pollution by bacteria, including the coli group, fungi and actinomycetes. The object of the analysis was the landfill of the Department for the Recovery and Storage of Municipal Waste in Leśno Górne. Analyses were performed in the four seasons of the year, taking into account the weather, status of the number of microorganisms and degree of risk to human health and life.

๑) IOŚ-PIB

\section{INTRODUCTION}

Although landfills and composting stations are a form of management and are designed to protect the natural environment, they adversely affect the quality of its components. Such negative effects particularly reflect the quality of atmospheric air in the neighbourhood of these facilities. Toxic and allergenic substances, microorganisms, and odours represent only some of the risks posed by landfills (Jurkiewicz et al. 1998).

Air quality monitoring is conducted by the service of environment protection and is based on the assessments of parameters such as moisture content and degree of contamination of chemical compounds (Jagusiewicz 1981). Simultaneously, the presence of microbial contamination exceeds standard air, what is evidenced by the data of Chief Sanitary Inspectorate. Both evolution and mutations of these organisms provide them a largescale adaptation to conditions of the environment and the development of civilisation which is related to a steady increase in the production of waste is the cause of this condition. Microorganisms in the air occur mainly in the form of a biological aerosol (Górny 2004, Krzysztofik 1992, Libudzisz et al. 2007). Air is only a way for them to transport and turbulence of air promotes the movement and the spread of masses of microorganisms for long distances, often in areas where they previously lived only in a monoculture (Kwaśna 2007). Bacteria that are present in the air transfer many dangerous pathogens and endotoxins, penetrating into organisms of animals and people through inhalation, skin or oral routes, which are dangerous to their health and life (Błaszczyk 2010).

Intensified production generates the need for landfill and both municipal and industrial waste. Microorganisms from municipal

\section{Streszczenie}

Składowiska odpadów komunalnych stanowią źródło skażenia mikrobiologicznego. Celem przeprowadzonych badań było określenie stopnia zanieczyszczenia powietrza przez bakterie, w tym z grupy coli, grzyby, oraz promieniowce. Obiektem analiz było składowisko Zakładu Odzysku i Składowania Odpadów Komunalnych w Leśnie Górnym. Analizy wykonano w czterech porach roku, z uwzględnieniem czynników pogodowych. Oceniono stan liczebności mikroorganizmów i stopień zagrożenia dla zdrowia i życia człowieka. landfills may be transferred into soil, surface water, groundwater and air, thus becoming a source of danger and contamination (Biernat et al. 2011, Traczewska, Karpińska-Smulikowska 2000, Jones, Cookson 1983)

The aim of microbiological study was to determine the degree of contamination of the air by bacteria, including Coliform bacteria, fungi and actinomycetes. The municipal landfill in the Department of the Recovery and Storage of Communal Waste (ZOiSOK) in Leśno Górne (Western Pomerania) is the object of analysis. Analyses were performed in four sessions, covering the four seasons of the year 2011/2012.

Studies were started by the laboratory, i.e. from the preparation of growth media, which after the field exposure were used to estimate the growth and number of microorganisms occurring in the neighbourhood of the analysed landfill.

\section{METHODS AND MATERIALS}

\section{a. Composition and preparation of culture media}

The following culture media were used in the study:

- MPA, i.e. nutrient agar (composition: peptone, meat extract, enzymatic hydrolyzate of casein, yeast extract, sodium chloride and agar, in accordance with standard PN-89, Z-04111/02)

- Czapek's-Dox (composition: sodium nitrate, magnesium sulphate, dipotassium ortho-phosphate, potassium chloride, ferric sulphate, sucrose and agar, in accordance with standard PN-89, Z-04111/03) 
- ENDO (composition: meat extract, peptone, sodium chloride, agar, lactose, sodium sulphate and $3 \%$ alkaline fuchsin solution, in accordance with standard PN-77, C-04615)

- Cyganov (composition: ammonium sulphate, dipotassium ortho-phosphate, magnesium sulphate, sodium chloride, calcium carbonate, starch and agar).

Methodology according to Nowak et al. (1995) was used for the preparation of culture media for different groups of microorganisms. After preparation, culture medium were sterilised for 30 minutes at the temperature $121^{\circ} \mathrm{C}$. After cooling up to the temperature $44^{\circ} \mathrm{C}$, the media were placed in Petri dishes, which were grouped. The medium was poured and uniformly distributed on each Petri (approx. $15-20 \mathrm{~cm}^{3}$ ), and then was allowed to solidify.

\section{b. Methods of field studies}

Municipal waste landfill in Leśno Górne is located approximately $7 \mathrm{~km}$ from Police (Fig. 1). In this study, the sedimentation method was used and a 15-minute exposure of plates was performed in seven research points: six points were distributed around the landfill and a control point was located approximately at $500 \mathrm{~m}$ (Fig. 2). Analyses were performed on four dates, 27.06.2011, 14.10.2011, 07.02.2012 and 16.04.2012, putting on a 15-minute exposure the three Petri each time for the three groups of microorganisms. Then the sample was subjected to incubation at room temperature (about $20^{\circ} \mathrm{C}$ for bacteria, fungi and actinomycetes), and for coli group bacteria at $37^{\circ} \mathrm{C}$. The incubation time for different groups of microorganisms was as follows: bacteria - 48 hours, fungi 72 hours, actinomycetes -7 days and coli group bacteria -7 days. Then number of colonies on each media was determined. The average number of microorganisms of three Petri exposed at the point to specific groups of microorganisms studied was taken from each measurement point per the final result.

To determine the number of microorganisms on the air in $1 \mathrm{~m}^{3}$ (in accordance to standard PN-89, Z-04111/03), the results were calculated according to the formula of Omeliański (modified Gogoberidze).

$$
x=\frac{\bar{a} \cdot 10^{4}}{\pi \cdot r^{2} \cdot 0,2 \cdot t}
$$

where:

$x$ - number of microorganisms in $1 \mathrm{~m}^{3}$;

$\bar{a}-$ the average number of colonies of microorganisms per surface of the Petri dish;

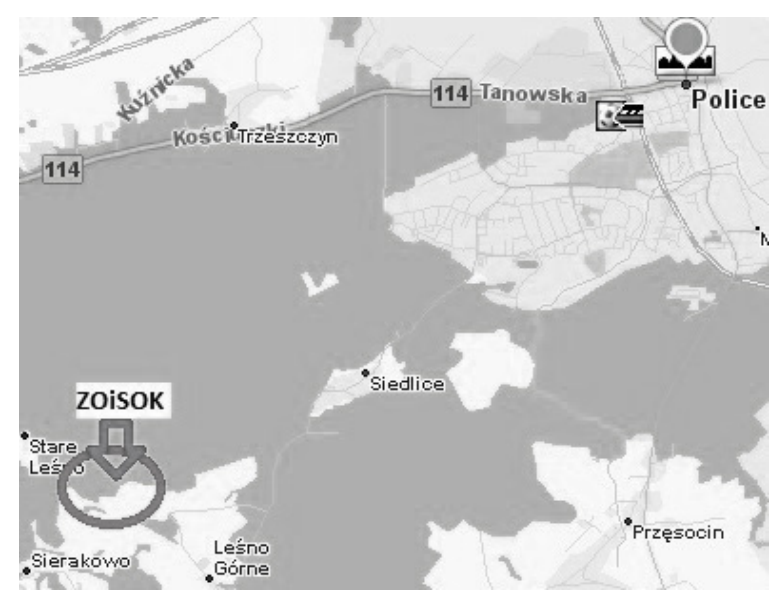

Fig. 1. Location the landfill ZOiSOK and the city Police (http://mapa.targeo.pl/Police/miasta) $r$ - radius of the Petri dish $(\mathrm{cm})$;

$t$ - exposure time ( $\mathrm{min})$;

0.2 - exposure time conversion coefficient of Petri dish

\section{RESULTS}

The microflora composition of atmospheric air evaluated within the analysed landfill shows significant differences in the number of each group of microorganisms.

Bacteria were the most numerous, and their numbers ranged between 169 and 91210 cells (Table 1). The minimum number of fungi was similar to them, but with a maximum of approximately nine times lower, between 127 and 11168 (Table 2). However, actinomycetes were characterised by a much lower abundance, because their number fluctuated within the limits between 0 and 5945 (Table 3). The smallest number was recorded for coli group bacteria (Table 4).

Simultaneously, the largest number of microorganisms was observed at high temperature and high humidity air (i.e. 16.04.2012). However, the smallest size was found at the lowest temperature and humidity of $91 \%$ on 07.02 .2012 (Table 5 ).

Analysis of the mean number of different groups of microorganisms concluded that the most numerous organisms were in the measuring points no. 2 and 6 where fresh waste was stored. This abundance was determined by a constant supply of organic matter and the optimum conditions favouring the processes of decay and rotting, which definitely contributed to the growth of the groups of microorganisms under study.

Coliform group of bacteria were the most numerous at point 4 in the older and the part of the landfill that is currently not in use, where the accumulation of "older" waste was the biggest.

The degree of air pollution by studied groups of microorganisms showed that the greatest impact on fluctuations in their numbers was the weather factors, especially humidity. This relationship was most evident at point numbers 4, 6 and 7 (Figs. 3-5).

The maximum number of bacteria (91210 cells), fungi (11168) and coli group bacteria (1486) at all points were at temperature of $3.9^{\circ} \mathrm{C}$ and air humidity of $79 \%$, with the predominant wind direction NW (Table 5). The maximum size of a group of actinomycetes (5945) reached at the temperature of $16.9^{\circ} \mathrm{C}$ and air humidity of $80 \%$, the winds direction $\mathrm{N}$. However, a minimum number of microorganisms were reported at $-1.4^{\circ} \mathrm{C}$ and $9.2^{\circ} \mathrm{C}$, and relative humidity $91 \%$ and $100 \%$, when the dominant winds were in the direction SW and NE. The greatest number of bacteria, fungi and coli group was recorded at the speed of wind $3.6 \mathrm{~m} / \mathrm{s}$. However, actinomycetes

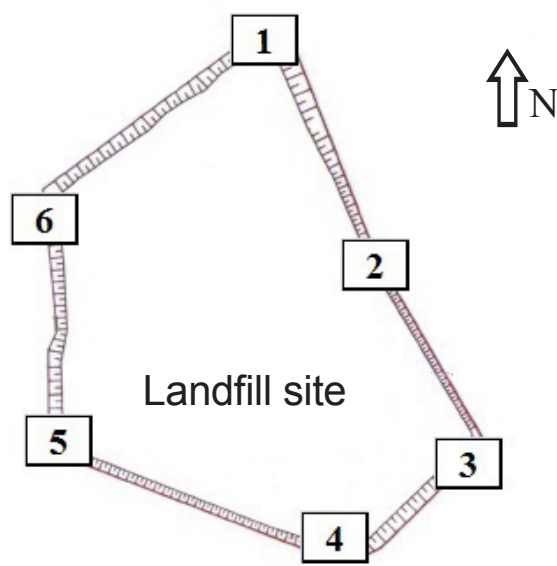

Fig. 2. Location of sampling points 


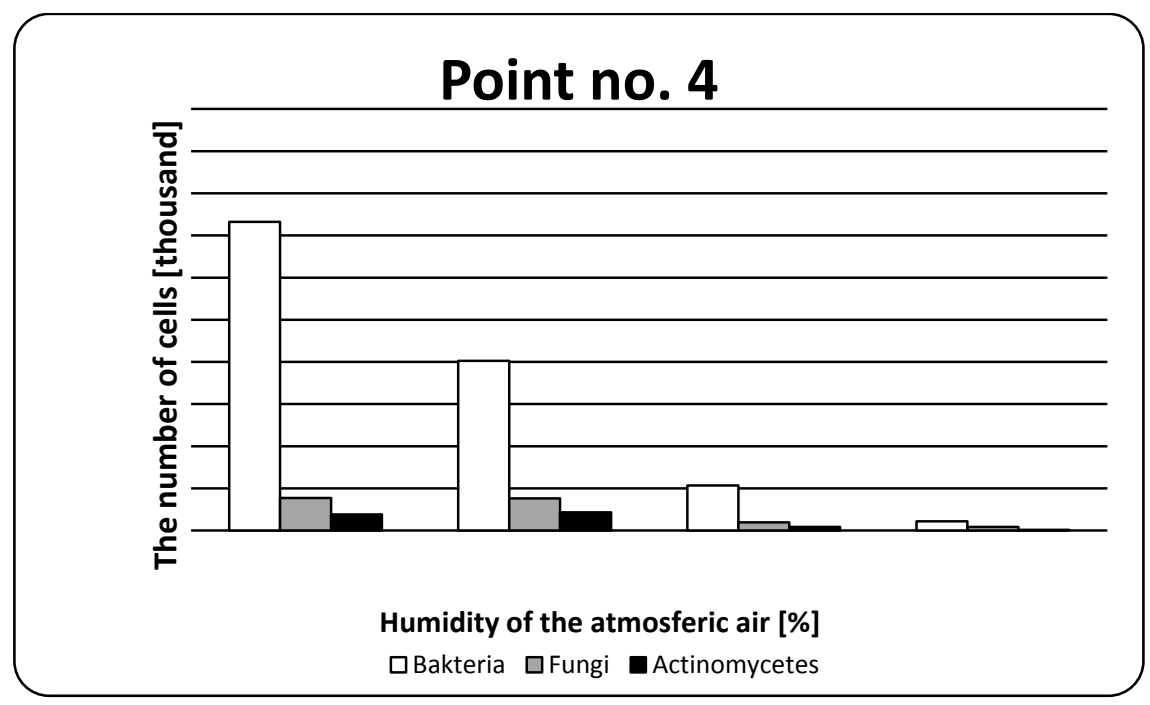

Fig. 3. Degree of humidity and the number of tested microorganisms

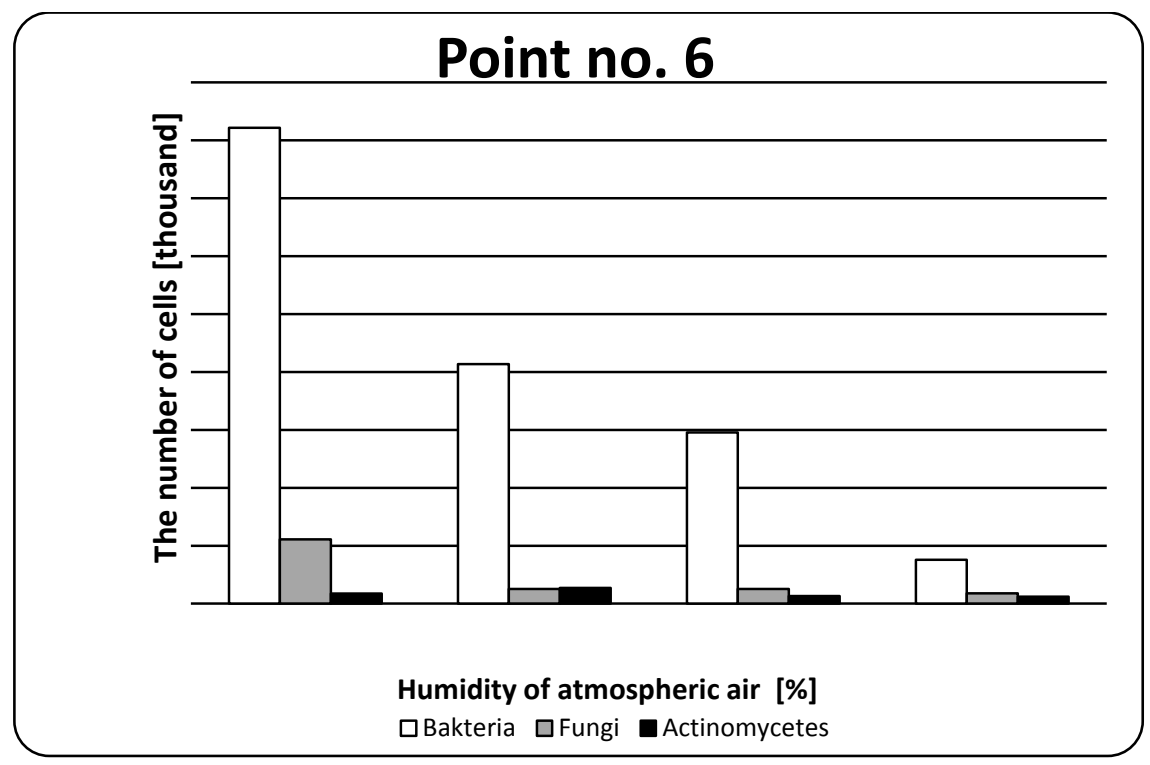

Fig. 4. Degree of humidity and the number of tested microorganisms

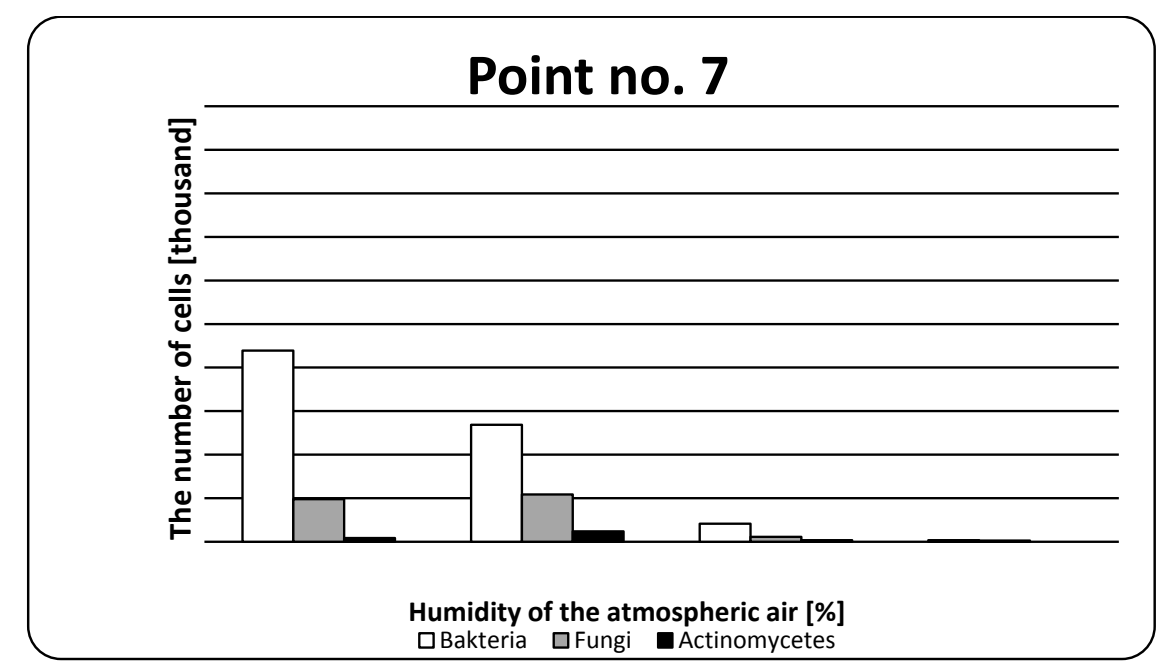

Fig. 5. Degree of humidity and the number of tested microorganisms 
were the most numerous at the speed $1.3 \mathrm{~m} / \mathrm{s}$. Analysis of the position of individual points within the landfill showed that most of the microorganisms occurred at downwind area of the landfill. In summary, evaluation of sample sizes of microorganisms and their fluctuations indicate that the optimal conditions for their growth are above zero temperatures and about $80 \%$ relative humidity.

The number of microorganisms at the control point was many times lower than in all other measuring points, thereby it was relatively decreasing with increasing of the distance from the landfill.

\section{DISCUSSION AND CONCLUSIONS}

Very high activity of the analysed groups of microorganisms has been shown on the basis of the results of the research. The most numerous bacteria occurred defining a strong degree of air pollution in standard PN-89/Z-04111/02. Estimated according to standard PN-89/Z-04111/03, fungi was another group of threatening organisms. In two cases, their amount was indicated as threatening to human environment. On the basis of standard PN-89/Z-04111/02, the number of actinomycetes showed a strong degree of air pollution. The bacteria of coli group were fairly numerous, but the lack of Polish standards made it impossible to determine the air pollution by this group (Traczewska, Karpińska-Smulikowska 2000). The results of sample sizes of microorganisms at the control point indicated the decrease in their numbers with increasing distance from the landfill. Similar relationships were shown by other authors who studied the microbiological pollution (Barabasz et al. 2005, Frączek 2004, Marska, Malinowska 2004, 2002).

The landfills are a source of infectious bioaerosol, which are very dangerous, during unfavourable weather conditions such as strong winds that may have a negative impact on human health through the rapid transfer and spread of pathogenic microorganisms (influenza, rubella, chicken pox, measles, tuberculosis, pneumonia, diphtheria or pertussis). Their presence causes a number of allergies and poisoning. Simultaneously, they are the cause of surface and deep fungal infections (aspergillosis and cryptococcosis). Further- more, the permanent exposure of the human body to these microorganisms (in excess of applicable standards) often results in the lack of or decreased immunity, skin rash and allergies. Microbes are also a source of epidemic diseases such as typhoid fever, plague, cholera and AIDS. Hence, the number of microorganisms and their level of emissions from landfills are the source of threats to human life and health (Kołwzan et al. 2005, Salyers, Whitt 2010).

Landfills have a significant impact on the sanitary status of atmospheric air in the environment, thus determining the level of threat to the health and life of biocenosis and people. For this reason, a consistent implementation of a system of barriers of protection becomes very important in the use of the landfill, which substantially limits the negative impact on the environment (Górny 2004).

The results obtained from this study enable to draw the following conclusions:

1. In Leśno Górne, the landfill site is the source of microorganisms, which spread in the atmosphere and constitute a threat to the environment and human health and life.

2. The number of microorganisms in atmospheric air decreases with increasing distance from the source of emission of pollutants - waste landfill.

3. Air pollution degree by microorganisms depends on the season and weather conditions including humidity, temperature, wind direction and speed.

4. The largest number of studied group of microorganisms was assessed for bacteria at all measurement points and at the specified dates. Their pollution of the air is a threat to human health and life. However, the minimum abundance was characterised by coli group of bacteria.

5. The number of actinomycetes revealed values indicating a strong threat to the environment and human lives.

6. Comparison of the results with the standards established in Poland indicates exceeding values were observed in all the investigated dates. The level of air pollution by all groups of microorganisms threatens the condition of the natural environment.

Table 1. Differentiation of bacteria in $1 \mathrm{~m}^{3}$ of atmospheric air in the tested measuring points

\begin{tabular}{|c|c|c|c|c|c|}
\hline No. of point & Term 1 & Term 2 & Term 3 & Term 4 & Average \\
\hline 1 & 11549 & 10403 & 2505 & 91210 & 28917 \\
\hline 2 & 59363 & 21104 & 10531 & 70955 & 40488 \\
\hline 3 & 14310 & 23397 & 29299 & 39448 & 26614 \\
\hline 4 & 20127 & 1104 & 5350 & 36603 & 15796 \\
\hline 6 & 27346 & 14777 & 12569 & 29469 & 21040 \\
\hline 7 & 41359 & 7558 & 29554 & 82166 & 40159 \\
\hline Average & 13418 & 169 & 2081 & 21953 & 9405 \\
\hline
\end{tabular}

Table 2. Differentiation in the number of fungi in $1 \mathrm{~m}^{3}$ of atmospheric air in the tested measuring points

\begin{tabular}{|c|c|c|c|c|c|}
\hline No. of point & Term 1 & Term 2 & Term 3 & Term 4 & Average \\
\hline 1 & 3057 & 425 & 255 & 11168 & 3726 \\
\hline 2 & 7006 & 1231 & 1359 & 6582 & 4045 \\
\hline 3 & 5265 & 3355 & 1231 & 5265 & 3779 \\
\hline 4 & 3822 & 425 & 977 & 3864 & 2272 \\
\hline 5 & 2760 & 1062 & 1953 & 2803 & 2145 \\
\hline 7 & 2548 & 1783 & 2548 & 11083 & 4491 \\
\hline Average & 5435 & 127 & 552 & 4883 & 2749 \\
\hline
\end{tabular}


Table 3. Differentiation in the number of actinomycetes in $1 \mathrm{~m}^{3}$ of atmospheric air in the tested measuring points

\begin{tabular}{|c|c|c|c|c|c|}
\hline No. of point & Term 1 & Term 2 & Term 3 & Term 4 & Average \\
\hline 1 & 2378 & 849 & 255 & 679 & 1040 \\
\hline 2 & 5945 & 1571 & 1656 & 1231 & 2601 \\
\hline 3 & 4544 & 1231 & 552 & 1019 & 1837 \\
\hline 4 & 2166 & 85 & 425 & 1911 & 1147 \\
\hline 5 & 2803 & 892 & 934 & 1571 & 1550 \\
\hline 6 & 2718 & 1189 & 1316 & 1741 & 1741 \\
\hline Average & 1189 & 0 & 169 & 425 & 446 \\
\hline
\end{tabular}

Table 4. Differentiation the number coli group bacteria in $1 \mathrm{~m}^{3}$ of atmospheric air in the tested measuring points

\begin{tabular}{|c|c|c|c|c|c|}
\hline No. of point & Term 1 & Term 2 & Term 3 & Term 4 & Average \\
\hline 1 & 0 & 127 & 0 & 679 & 202 \\
\hline 2 & 255 & 169 & 85 & 595 & 276 \\
\hline 3 & 212 & 169 & 43 & 255 & 170 \\
\hline 4 & 297 & 43 & 43 & 1486 & 467 \\
\hline 5 & 127 & 85 & 43 & 85 & 85 \\
\hline 6 & 255 & 85 & 85 & 339 & 191 \\
\hline 7 & 0 & 0 & 0 & 1062 & 266 \\
\hline
\end{tabular}

Table 5. Weather conditions on the dates of sample collection

\begin{tabular}{|c|c|c|c|c|}
\hline \multirow{2}{*}{ Term } & \multicolumn{4}{|c|}{ Weather conditions } \\
\hline 27.06 .2011 & Temperature $\left[{ }^{\circ} \mathrm{C}\right]$ & Wind speed $[\mathrm{m} / \mathrm{s}]$ & Wind direction & Humidity $[\%]$ \\
\hline 14.10 .2011 & 16,9 & 1,3 & $\mathrm{~N}$ & 80 \\
\hline $\mathbf{0 7 . 0 2 . 2 0 1 2}$ & 9,2 & 2,1 & $\mathrm{NE}$ & 100 \\
\hline 16.04 .2012 & $-1,4$ & 1,9 & $\mathrm{SW}$ & 91 \\
\hline
\end{tabular}

(based on: http://www.wios.szczecin.pl/bip/chapter_16156.asp)

\section{REFERENCES AND LEGAL ACTS}

BARABASZ W., ALBIŃSKA D., BARABASZ J. 2005. Obiekty komunalne jako źródło bioaerozolu i mikroorganizmów szkodliwych dla zdrowia. Referat Ogólnopolskiej Sesji Popularnonaukowej „Środowisko a zdrowie”. Częstochowa.

BŁASZCZYK M.K., 2010. Mikrobiologia środowisk. Wydawnictwo Naukowe PWN SA, Warszawa.

BIERNAT K., DZIOŁAK P.L., SAMSON-BRĘK I., 2011. Stan i prognoza rozwoju systemu gospodarki odpadami w Europie i USA. Stud. Ecol. Bioethic., Tom 9 nr 1: 101-123.

FRACZCZEK K. 2004. Microbiological studiem of atmospheric air in the impast zone of the municipal landfill site in Krzyż near Tarnów. Acta Agraria Et Silvestria, series 42: 97-105.

GÓRNY L.R. 2004. Biologiczne czynniki szkodliwe: normy, zalecenia i propozycje wartości dopuszczalnych. Podstawy i Metody Oceny Środowiska Pracy, nr 3 (41): 17-39.

JAGUSIEWICZA. 1981. Powietrze - człowiek - środowisko. LSW, Warszawa.

JONES B.L., COOKSON J.T. 1983. Natural atmospheric microbial conditions in a typical suburban area. Appl. Environ. Microbiol. 45,3: 919-934.

JURKIEWICZ G., MARKIEWICZ P., SKORUPSKI W. 1998. Zorganizowane składowisko odpadów komunalnych jako źródło zanieczyszczeń powietrza. Chemia i Inżynieria Ekologiczna. Opole, 5,7: 583-593.

KOŁWZAN B., ADAMIAK W., GRABAS K., PAWEŁCZYK A. 2005. Podstawy mikrobiologii w ochronie środowiska. Oficyna Wydawnicza Politechniki Wrocławskiej. Wrocław.

KRZYSZTOFIK K. 1992. Mikrobiologia powietrza. Politechnika Warszawska. Warszawa.

KWAŚNA H. 2007. Mikrobiologia dla studentów uczelni rolniczych. Wydawnictwo Akademii Rolniczej im. Augusta Cieszkowskiego w Poznaniu. Poznań.

LIBUDZISZ Z., KOWAL K., ŻAKOWSKA Z. 2007. Mikrobiologia techniczna. Tom I. Wydawnictwo Naukowe PWN. Warszawa.

MARSKA B., MALINOWSKA K. 2002. Wpływ bioaerozoli emitowanych przez oczyszczalnie ścieków na jakość mikrobiologiczną powietrza. Folia Univ. Agricult. Stetin. 226 (90): 163-170.

MARSKA B., MALINOWSKA K. 2004. Występowanie bakterii Escherichia coli w powietrzu i w glebie w rejonie oddziaływania emisji z biologicznych oczyszczalni ścieków. Acta Agraria Et SiIvestria. 17:271-278.

NOWAK A., MARSKA B., WRONKOWSKA H., MICHALCEWICZ W. 1995. Przewodnik do ćwiczeń z mikrobiologii. Wydawnictwo Akademii Rolniczej w Szczecinie. Szczecin. 
PN-89/Z-04111/02. Ochrona czystości powietrza. Badania mikrobiologiczne. Oznaczanie liczby bakterii w powietrzu atmosferycznym (imisja) przy pobieraniu próbek metoda aspiracyjną i sedymentacyjną. 1989. Polski Komitet Normalizacji Miar i Jakości. Warszawa.

PN-89/Z-04111/03. Ochrona czystości powietrza. Badania mikrobiologiczne. Oznaczanie liczby grzybów mikroskopowych w powietrzu atmosferycznym (imisja) przy pobieraniu próbek metodą aspiracyjną i sedymentacyjną. 1989. Polski Komitet Normalizacji Miar i Jakości. Warszawa.
PN-77/C-04615/07. Woda i ścieki. Badania mikrobiologiczne. Oznaczanie bakterii grupy coli typu kałowego (feralnego) metodą fermentacyjną probówkową. 1977. Polski Komitet Normalizacji Miar i Jakości. Warszawa.

SALYERS A., WHITT D. 2010. Mikrobiologia różnorodność, chorobotwórczość i środowisko. Wydawnictwo Naukowe PWN. Warszawa.

TRACZEWSKA T.M., KARPIŃSKA-SMULIKOWSKA J. 2000. Wpływ składowiska odpadów komunalnych na jakość mikrobiologiczną powietrza. Ochrona Środowiska 2: 35-38. 